\title{
MIR192 Gene
}

National Cancer Institute

\section{Source}

National Cancer Institute. MIR192 Gene. NCI Thesaurus. Code C81748.

This gene is involved in the regulation of gene expression and plays a role in the development of ulcerative colitis. 